\title{
METHYLMERCURY INHIBITS GROWTH AND INDUCES MEMBRANE CHANGES IN Pseudomonas putida
}

\author{
Maša VODOVNIK ${ }^{1}$, Mirjana BISTAN ${ }^{2}$, Maša ZOREC ${ }^{3}$, Romana MARINŠEK LOGAR ${ }^{4}$
}

Received October 08, 2010; accepted November 22, 2010. Delo je prispelo 08. oktobra 2010, sprejeto 22. novembra 2010.

\begin{abstract}
Methylmercury inhibits growth and induces membrane changes in Pseudomonas putida

A bacterial model system (Pseudomonas putida DSM 50026) was used in this research to assess toxicity of the environmentally relevant concentrations of mercury species $(\mathrm{MeHg}$ and $\mathrm{Hg}(\mathrm{II})$ ) that represent important pollutants of aquatic ecosystems at sites of industrial or mining activities. In addition to direct monitoring of bacterial growth, we also analyzed fatty acid profiles of exposed and non-exposed cultures to determine possible toxic effects manifested on membrane level. The results showed that exposure of $P$. putida to $\mathrm{Hg}(\mathrm{II})$ in concentrations of $0.2-200 \mu \mathrm{g} / \mathrm{L}$ did not have any significant effects on growth nor fatty acid composition of exposed bacterial culture. On the other hand, when bacteria were exposed to up to 1600 -times lower concentrations of $\mathrm{MeHg}(0.12-12.5 \mu \mathrm{g} / \mathrm{L})$, growth inhibition as well as significant changes in fatty acid composition were detected. Observed adaptive membrane changes due to $\mathrm{MeHg}$ exposure were similar to those associated with responses to organic solvents and some other membrane-disrupting compounds.
\end{abstract}

Key words: microbiology / environmental protection / bacteria / Pseudomonas putida / aquatic ecosystems / pollution / mercury / methylmercury / growth inhibition / membrane adaptation / cis-trans isomerization

\section{INTRODUCTION}

In the past few decades, environmental pollution has become one of the world's major concerns. Heavy metals are a group of pollutants representing environmental problem in most parts of the world. One of the

\begin{abstract}
Metil živo srebro inhibira rast in povzroča spremembe v membranah bakterije Pseudomonas putida

$\mathrm{V}$ raziskavi smo na bakterijskem modelu (Pseudomonas putida DSM 50026) analizirali strupenost okoljskih koncentracij anorganske $(\mathrm{Hg}(\mathrm{II}))$ in organske $(\mathrm{MeHg})$ oblike živega srebra, ki predstavljata pomembna vira onesnaženja vodnih ekosistemov v bližini nekaterih industrijskih in rudarskih območij. Poleg neposrednega spremljanja bakterijske rasti smo analizirali tudi maščobnokislinske profile izpostavljenih bakterijskih kultur in jih primerjali s tistimi, ki živosrebrovima spojinama niso bili izpostavljeni. Rezultati so pokazali, da izpostavitev $P$. putida $\mathrm{Hg}(\mathrm{II}) \mathrm{v}$ koncentracijah med 0,2 in $200 \mu \mathrm{g} / \mathrm{L}$ ne inhibira rasti, niti ne vpliva na maščobnokislinsko sestavo bakterijskih membran. Nasprotno pa je izpostavitev celic do 1600-krat nižjim koncentracijam $\mathrm{MeHg}$ povzročila tako upočasnitev rasti kot tudi prilagoditvene spremembe na membranskem nivoju. Slednje so bile podobne kot tiste, opažene ob izpostavitvi bakterij organskim topilom in nekaterim drugim spojinam, ki motijo integriteto membran.

Ključne besede: mikrobiologija / varstvo okolja / bakterije / Pseudomonas putida / vodni ekosistemi / onesnaževanje / živo srebro / metil živo srebro / inhibicija rasti / membranska adaptacija / cis-trans izomerizacija
\end{abstract}

most toxic metals is certainly mercury, which represents a significant concern especially in aquatic ecosystems at sites with industrial or mining activities. Mining operations in areas rich in cinnabar ore may represent strong sources of $\mathrm{Hg}$ for many years even after mining has been discontinued (Benoit et al., 1994). One of mercury (Hg) affected sites also lies in Western part of Slovenia where

1 Univ. of Ljubljana, Biotechnical Fac., Dept. of Animal Science, Groblje 3, SI-1230 Domžale, Slovenia, e-mail: masa.vodovnik@bf.uni-lj.si

2 Laboratory for environmental science and engineering, National institute of chemistry, Hajdrihova 19, SI-1000 Ljubljana, Slovenia

3 Same address as 1, Ph.D.

4 Same address as 1, Ph.D., e-mail: romana.marinsek@bf.uni-lj.si 
lies the second largest $\mathrm{Hg}$ mine in the world. The Idrija Mine operated for 500 years until its closure in 1994, but mercury laden tailings still line the banks and the system is a threat to the Idrija River and water bodies downstream, including the Soča / Isonzo River and the Gulf of Trieste in the northern Adriatic Sea, which are therefore subjects to continuous environmental monitoring (Hines et al., 2000; Faganeli et al., 2003).

Mercury can cause acute as well as chronic poisoning in animals and humans (Sweet \& Zelnikoff, 2001; Crespo-Lopez et al., 2007; Han et al., 2008). The most toxic forms of mercury are usually considered to be organic compounds, such as methylmercury $(\mathrm{MeHg})$ and dimethylmercury $\left(\mathrm{Me}_{2} \mathrm{Hg}\right)$, which have the tendency to accumulate in hydrophobic environments such as cell membranes (Mason et al, 1996; Girault et al., 1997). Bioaccumulation on different trophic levels leads to biomagnification effect in natural ecosystems, which means that even low levels of organic mercury compounds in the environment may have detrimental effect on organisms at the end of the food chain (Mason et al., 1996). However, not all the mercury that is present in natural ecosystems is bioavailable and therefore harmful to the living organisms (Golding et al., 2007). Standard chemical analytical methods do not have the power to discriminate between bioavailable and fixed forms of mercury in environmental samples and therefore need to be complemented with methods, based on responses of living (micro)organisms for proper risk assessment (Farre et al. 2005). Living cells (organisms) can be used as bioindicators, as well as testspecies in bioassays. By recent establishment of modern 3R concept (reduction, replacement, refinement), the development and application of bioassays based on microbial cells is being promoted, due to their simple cultivation in axenic cultures and lack of ethical issues usually present when using higher organisms (Marinšek Logar and Vodovnik, 2007).

Cell membrane as the first barrier separating cellular interior from its environment represents a primary defense line against unfavorable environmental impacts and therefore appears to be a good target for ecophysiological as well as toxicological studies. Bacteria are known to react to several environmental triggers by modifying fatty acid composition of their membranes, predominantly by changing the ratio of saturated to unsaturated fatty acids (Cronan 2002). However, several strains of ubiquitous bacterium Pseudomonas putida have been shown to use at least three adaptation mechanisms at membrane level which apply to different types of environmental stressors: (1) changes in the overall degree of saturation of fatty acids (Loffhagen et al. 2004), (2) the formation of cyclopropane fatty acids (Härtig et al. 2005) and (3) cis-trans isomerization (von Wallbrun et al. 2003). Meanwhile the first two responses are mainly associated with temperature stress and starvation, cistrans isomerization, appears to be involved in toxic stress defence (Heipieper et al. 1995; Heipieper et al. 1996). It has been shown in solvent-tolerant strains of $P$. putida that toxicity and concentration of organic solvents in their membrane correlate with increase in trans/cis fatty acid ratio (Heipieper et al. 1992; Heipiepper et al. 1994; Weber et al., 1996). Moreover, several heavy metal ions, namely $\mathrm{Zn}^{2+}, \mathrm{Cd}^{2+}, \mathrm{Cr}^{3+}, \mathrm{Co}^{2+}, \mathrm{Cu}^{2+}$ and $\mathrm{Ni}^{2+}$ have also been shown to induce adaptive changes resulting in increased accumulation of trans fatty acids (Heipieper et al. 1996). However, there are so far no reports on effects of mercury (Hg) species on P. putida (or other bacterial) membranes, which is the objective of this article. Our hypothesis was that organic ( $\mathrm{MeHg}$ ), as well as inorganic ( $\mathrm{Hg}(\mathrm{II}))$ form of mercury may influence the membrane (fatty acid profile) of $P$. putida. However, due to its hydrophobic nature, the degree to which membranes are affected was expected to be larger in case of $\mathrm{MeHg}$.

\section{MATERIALS AND METHODS}

\subsection{MICROORGANISM}

P. putida DSM 50026 cells were purchased in freezedried form from Deutsche Sammlung von Mikroorganizmen und Zellkulturen GmbH (DSMZ, 1998).

\subsection{CHEMICALS}

General reagents dimethylsulfoxide (DMSO), methanol, $\mathrm{n}$-hexane and glycerol as well as both mercury species: $\mathrm{MeHg}$ in the form of $\mathrm{CH}_{3} \mathrm{HgCl}$ and $\mathrm{Hg}(\mathrm{II})$ in the form of $\mathrm{HgCl}_{2}$ were purchased from Sigma (St. Luis, $\mathrm{MO}$, USA) or Merck (Darmstadt, Germany). Bacteriological agar and peptone were purchased from Biolife (Milan, Italy) and meat extract from Becton Dickinson (New Jersey, NJ, USA). Standard calibration mixture of bacterial FAME in methyl-caproate (BAME standard) was purchased from Sigma (St. Luis, MO, USA) and standard calibration mixture of bacterial FAMEs in hexane (MIDI standard) was purchased from Hewlett Packard (USA).

\subsection{CULTURE CONDITIONS}

P. putida DSMZ 50026 was cultivated for 20 hours in medium described by DSMZ (1998) containing $3 \mathrm{~g}$ of meat extract and $5 \mathrm{~g}$ of bacteriological peptone per 
Table 1: Concentrations of tested mercury species

Preglednica 1: Koncentracije testiranih živosrebrovih spojin

\begin{tabular}{lcclc}
\hline Tested compound & \multicolumn{5}{c}{ Concentrations $(\mu \mathrm{g} / \mathrm{L})$} \\
\hline $\mathrm{HgCl}_{2}(\mathrm{Hg}(\mathrm{II}))$ & 200 & 20 & 2 & 0.2 \\
$\mathrm{CH}_{3} \mathrm{HgCl}(\mathrm{MeHg})$ & 12.5 & 1.25 & 0.12 & - \\
\hline
\end{tabular}

$1000 \mathrm{ml}$ of distilled water $\left(\mathrm{dH}_{2} \mathrm{O}\right)$. Cells were grown in 10 $\mathrm{ml}$ test-tubes, at $27^{\circ} \mathrm{C}$ (without shaking).

\subsection{EXPOSURE CONDITIONS}

After 20 hours incubation, selected environmentally relevant concentrations (Quiu et al., 2006) of tested mercury species (Table 1) were added to the cultures. $\mathrm{MeHg}$, which is water insoluble, was dissolved in $50 \%$ DMSO instead of distilled water before added to the culture medium. Negative controls for those samples were performed with the addition of an adequate amount of DMSO as well. Cells exposed to tested concentrations of mercury species were incubated for another 24 hours at $27^{\circ} \mathrm{C}$. During incubations, growth was followed by measuring optical density at $654 \mathrm{~nm}$ by Novaspec II Visible Spectrofotometer. Cells were harvested by centrifugation $\left(3000 \mathrm{rpm}, 4^{\circ} \mathrm{C}, 10 \mathrm{~min}\right)$. Pellets were resuspended in sterile double distilled water $(1 \mathrm{~mL})$, frozen $\left(-20^{\circ} \mathrm{C}\right)$ and freeze-dried.

\subsection{LIPID EXTRACTION AND TRANSESTERIFI- CATION}

Bacterial lipids were extracted from freeze dried samples and transesterified using modified $\mathrm{HCl} /$ methanol procedure that has already been described before (Ivancic et al., 2009).

\subsection{GAS CHROMATOGRAPHY}

Fatty acid methyl esters (FAMEs) extracts in hexane were analyzed on gas chromatograph Shimadzu GC-14A equipped with flame ionization detector (FID). Capillary column (Equity-1; Supelco, 28046-U) with non-polar stationary phase (100\% poly-dimethyl-siloxane) was used. The analysis followed the temperature program: temperature gradient from 150 to $250{ }^{\circ} \mathrm{C}$ at $4{ }^{\circ} \mathrm{C} \mathrm{min}{ }^{-1}$. The flow rate of carrier gas $(\mathrm{He})$ was $30 \mathrm{ml} \mathrm{min}^{-1}$. The injector temperature was held at $250{ }^{\circ} \mathrm{C}$ and detector at $280{ }^{\circ} \mathrm{C}$. The results were registered on Chromatopac C-R6A integrator. Relative proportions of fatty acids between $\mathrm{C} 10$ and $\mathrm{C} 20$ were calculated from peak areas. Identification was done either directly by comparison of retention times of unknown peaks with standard fatty acid calibration mixtures (BAME, MIDI; SIGMAAldrich) or indirectly by equivalent chain length (ECL) factors calculation (Mjøs, 2003).

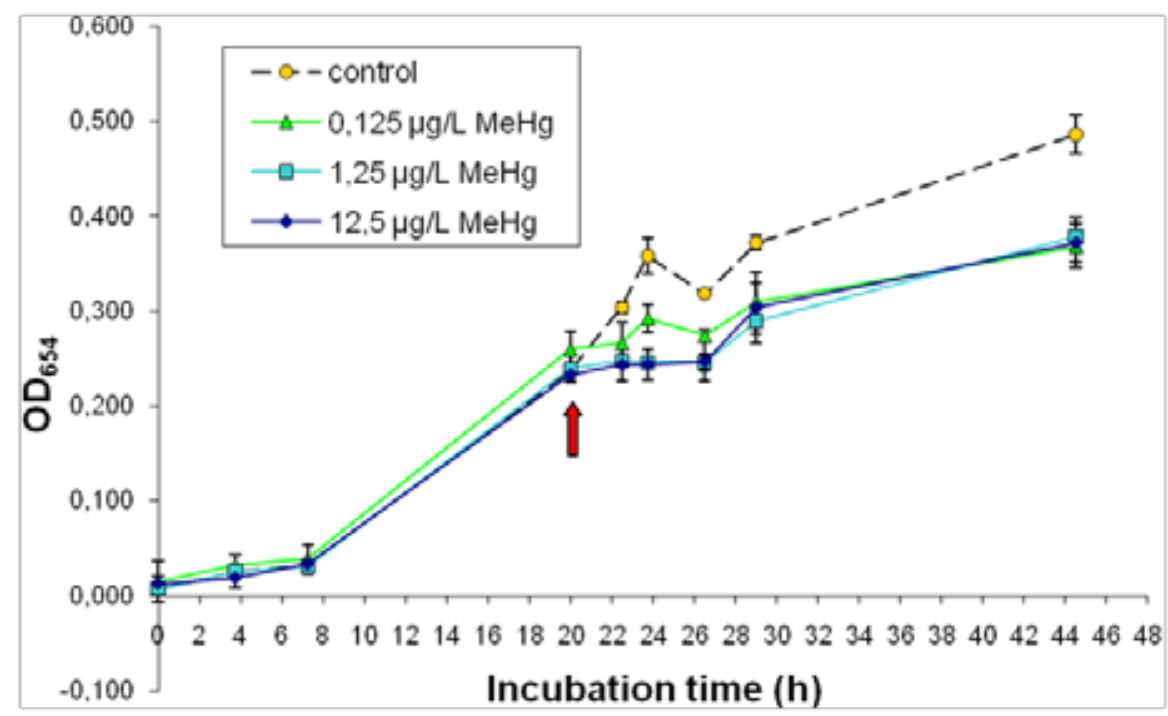

Figure 1: Growth curves of P. putida DSM 50026 culture exposed to MeHg in concentrations from 0.12 to $12.5 \mu \mathrm{g} / \mathrm{L}$ in comparison to non-exposed cells (control). The time of MeHg addition is marked by arrow.

Slika 1: Rastne krivulje kulture P. putida DSM 50026 izpostavljene MeHg v koncentracijah od 0,12 do 12,5 $\mu \mathrm{g} / \mathrm{L} v$ primerjavi s kontrolno (neizpostavljeno) kulturo. Začetni čas izpostavitve MeHg je označen s puščico. 


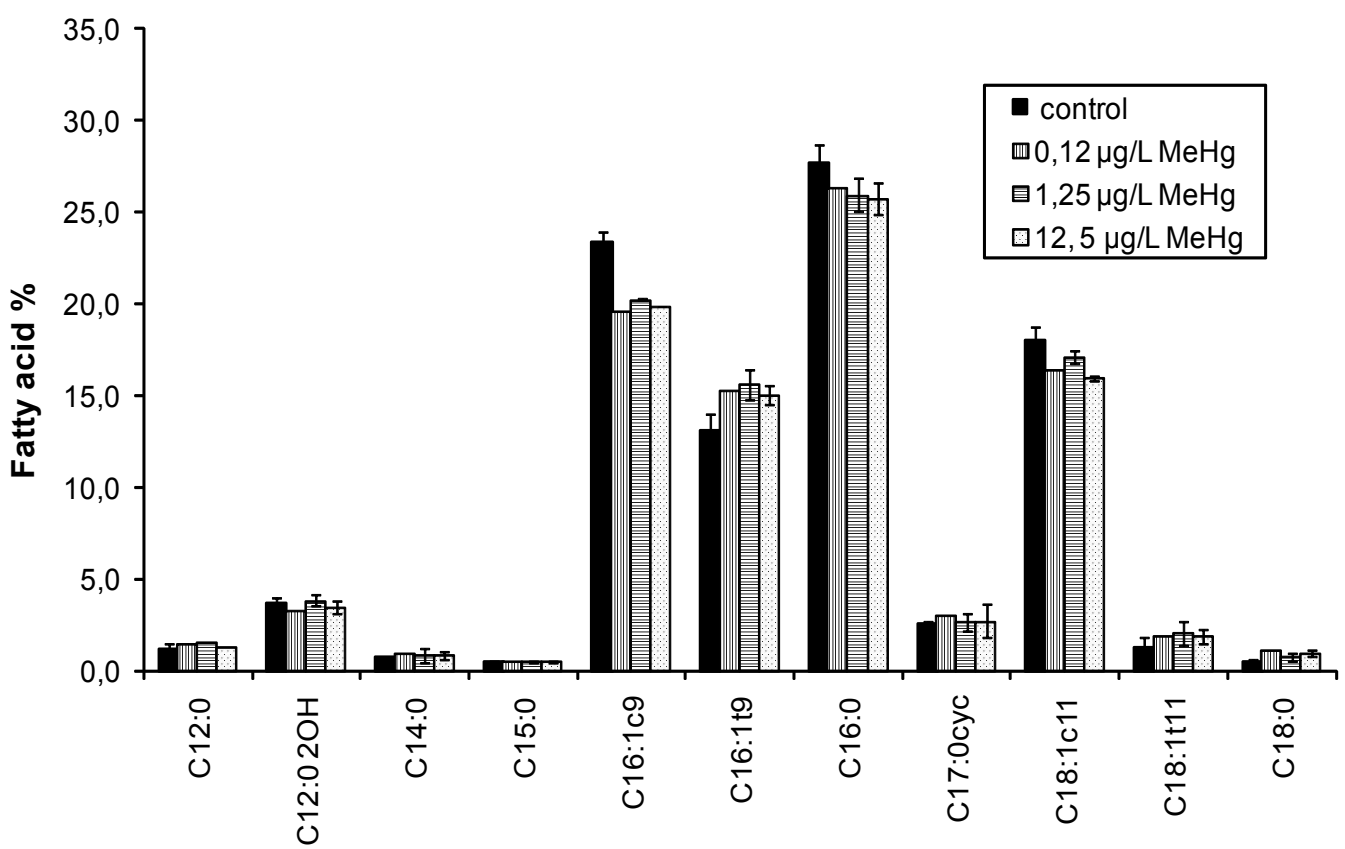

Figure 2: Changes in fatty acid profile of P. putida DSM 50026 culture exposed to MeHg in concentrations from 0.12 to $12.5 \mu \mathrm{g} / \mathrm{L}$. Slika 2: Spremembe v maščobnokislinskem profilu kulture P. putida DSM 50026 ob izpostavitvi MeHg v koncentracijah od 0,12 $\mu g / L$ do $12,5 \mu g / L$.

\subsection{CALCULATIONS}

Membrane fatty acids which were present in less than $0.5 \%$ of total fatty acids were signed as fatty acids in traces and were not considered for further interpretation.

Trans/cis ratio of unsaturated fatty acids was calculated according to Heipieper et al., 1995.

\subsection{STATISTICAL ANALYSIS}

All the exposures were performed in 4 parallel samples. The data was statistically analyzed using Student's t-test with significance level of 0.05 .

\section{$3 \quad$ RESULTS}

Our experiments showed that exposure of $P$. putida DSM 50026 to $\mathrm{HgCl}_{2}$ in concentrations of $0.2-200 \mu \mathrm{g} / \mathrm{L}$ did not result in any significant effects on growth nor fatty acid composition of exposed bacterial culture (results not shown). However, when bacteria were exposed to organic mercury in form of $\mathrm{CH}_{3} \mathrm{HgCl}$ (from $0.12-12.5$ $\mu \mathrm{g} / \mathrm{L}$ ) growth inhibition as well as significant changes in fatty acid composition were observed (Figures 1,2).
Most significant (dose-effect) inhibition of cell growth occurred in the first 4-6 hours after exposure of cells to $\mathrm{MeHg}$. After 8 hours of growth in $\mathrm{MeHg}$ supplemented medium, cell culture appeared to grow with approximately the same (attenuated) rate, regardless of mercury concentration. The behavior of growth curves that can be observed in Fig. 1 suggests the possibility of adaptive changes of microbial cells, enabling the culture to continue growing under the changed conditions. Since the membrane represents the primary barrier between cells and the environment and is responsible to regulate the flow of molecules into (and out of) the cell, we decided to focus our research on possible adaptive changes that may be detected on lipid level. Our results show that exposure of P. putida to $\mathrm{MeHg}$ in concentrations between 0.12$12.5 \mu \mathrm{g} / \mathrm{L}$ significantly influences fatty acid profile of tested bacteria, resulting in increase of trans/cis fatty acid ratio from $0.35 \pm 0.04$ (in non-exposed cells) to $0.47 \pm$ 0.02 (in cells exposed to $0.12 \mu \mathrm{g} / \mathrm{L}$ or $1.25 \mu \mathrm{g} / \mathrm{L} \mathrm{MeHg}$ ) or $0.48 \pm 0.03$ (in cells exposed to $12.5 \mu \mathrm{g} / \mathrm{L}$ ). The observed shift in trans/cis ratio is mainly associated with statistically significant decreases in C16:1cis9 and C18:1cis11 fatty acids, accompanied by increase in C16:1trans 9 . 


\section{DISCUSSION}

Little is known about the molecular mechanisms controlling (methyl)mercury uptake and toxicity so far. The primary targets of both, $\mathrm{CH}_{3} \mathrm{Hg}$ (II) as well as inorganic $\mathrm{Hg}(\mathrm{II})$, are considered sulfhydril-containing macromolecules (especially of various molecular weight thiol-containing proteins). Covalent binding of mercury compounds to proteins acting as antioxidants (i.e. glutathione) or components of electron transport chains appears to be associated with free radical accumulation, leading to oxidative damage of macromolecules and lipid peroxidation (Patrick, 2002; Han et al., 2008). Despite the generally recognized common molecular targets, the levels of mercury species inducing toxicity usually differ. It is generally assumed that $\mathrm{MeHg}$ is the most toxic $\mathrm{Hg}$ species, which is often ascribed to its higher lipid solubility (Sweet, 2001). However, the octanol/water partition coefficients $\left(\mathrm{K}_{\mathrm{ow}}\right)$ of uncharged $\mathrm{HgCl}_{2}$ and $\mathrm{CH}_{3} \mathrm{HgCl}$ species do not differ significantly (3.3 and 1.7 respectively) (Broniatowski, 2009). These data suggest that the actual interaction of the $\mathrm{Hg}$ species with the cell membranes is very much dependent on the environmental factors influencing their ionization as well as membrane charge (especially pH and the types, as well as concentrations of ions present in the solution) (Sweet, 2001).

Only few studies on methylmercury binding to biomembrane lipids have been reported. Early "in vitro" studies suggested a direct mechanism of $\mathrm{CH}_{3} \mathrm{Hg}$ (II) action on selected lipids. Segal \& Wood (1974), for example, performed an NMR study which showed that $\mathrm{MeHg}$ can react both catalytically and directly with plasmalogens (a group of phospholipids which are important in a membrane structure for cells of the central nervous system of higher organisms). They showed that $\mathrm{MeHg}$ ion is soluble in phospholipids and catalyses rapid hydration and hydrolysis of the vinyl ether linkage to give a mixture of palmitic and stearic aldehydes plus the linolenic monoglyceride product (Segal and Wood, 1974). Furthermore, studies performed by LeBlanc et al. (1984) revealed a $\mathrm{pH}$-dependent binding of $\mathrm{MeHg}$ to acidic phosphatidylserine (PS) and phosphatidylinositol (PI) phospholipids, but not to zwitterionic phosphatidilcholine (PC) and sphingomielin (SM). The most extensive study on $\mathrm{MeHg}$ interaction with phospholipid membranes is probably the one performed by Girault et al.(1997), in which the authors used three complementary approaches: (i) ${ }^{199} \mathrm{Hg}$-NMR which quantitatively describes MeHg mobility and complexation, both in solution and at the membrane interface, (ii) fluorescence polarization which reveals dynamic changes of the hydrophobic interior and (iii) solid state ${ }^{31} \mathrm{P}-\mathrm{NMR}$ which is indicative of the phosphate group structure and mobility and allows detection of non-bilayer phases. The study revealed that $\mathrm{CH}_{3} \mathrm{Hg}(\mathrm{II})$ interactions with membrane lipids are electrostatic in nature and primarily depend on the polar head groups negative charges (phosphate moiety), which is not the case with $\mathrm{HgCl}_{2}$ (Delnomdedieum et al., 1992; Girault et al. 1997). Extensive metal binding (up to three MeHg molecules per lipid) induces limited membrane destabilization, which may, in some cases, be associated with loss of its integrity (Girault et al., 1997).

Our results confirmed the hypothesis that effects of mercury compounds on P. putida cells essentially depend on their chemical structures. Meanwhile chosen concentrations of inorganic mercury in form of $\mathrm{HgCl}_{2}$, did not inhibit growth nor induced any adaptive changes in bacterial membranes the opposite was the case with its methylated form. MeHg exhibited toxicity that reflected at both levels (culture growth as well as membrane changes) at concentrations up to 1600-times lower that the highest $\mathrm{Hg}(\mathrm{II})$ concentration tested. Most significant inhibition of cell growth occurred in the first 4-6 hours after exposure to MeHg. After 8 hours of growth in $\mathrm{MeHg}$ supplemented medium, cell culture appeared to grow with approximately the same (slightly attenuated) rate, regardless of methylmercury concentration. The lack of dose-effect inhibition at this stage may indicate that differences in chosen concentrations were too small to inhibit significantly different proportions of cells that would be observable by spectrophotometric measurements. However, the behavior of growth curves that can be observed in Fig. 1 suggests the possibility of adaptive changes in certain number of microbial cells that have survived the $\mathrm{MeHg}$ presence, enabling the cultures to continue growing under the changed conditions.

Observed membrane changes associated with $\mathrm{MeHg}$ exposure resulted in overall increase in trans/cis fatty acid ratio, indicating the prevalent isomerization of cis- to trans- unsaturated fatty acids. This adaptive response is known to be associated with decrease in membrane fluidity, enabling Pseudomonas strains to grow in the presence of membrane-disrupting compounds (Von Wallbrun et al., 2003; Härtig et al., 2005). The same type of response has already been described when selected $P$. putida strains were exposed to toxic concentrations of toluene (Weber et al., 1994; Heipieper et al., 1994), phenol (Heipieper et al., 1992), ethanol (Heipieper et al., 1994) and six different heavy metals, namely $\mathrm{Zn}^{2+}, \mathrm{Cd}^{2+}$, $\mathrm{Cr}^{3+}, \mathrm{Co}^{2+}, \mathrm{Cu}^{2+}$ and $\mathrm{Ni}^{2+}$ (Heipieper et al., 1996). The degree of isomerization was shown to depend on the toxicity and the concentration of membrane-affecting agents. The described way of membrane adaptation is performed by cis-trans-isomerase (Cti), a constitutively expressed periplasmic enzyme that, to exert its action, necessitates neither ATP nor other cofactors, and consistently, is in- 
dependent of de novo synthesis of lipids. Due to its direct correlation with toxicity, cis-trans-isomerization is a potential biomarker for recording solvent stress or changes of other environmental conditions (Bernal et al., 2007; Heipieper et al., 2010). The question that needs to be addressed at this point is how do $P$. putida cells detect the presence of membrane disrupting compounds like $\mathrm{MeHg}$, which leads to activation of protective mechanism(s). In the presence of organice solvents, the detection and activation appears to be directly associated with detected increase in membrane microviscosity caused by changes of the acyl chain order (Killian et al., 1992). According to Neumann et al., the hydrophilic structure and periplasmic location of Cti supports the assumption that the enzyme can only reach its target (the double bonds of unsaturated fatty acids that are located at a certain depth of the membrane) when the membrane is destabilized (i.e. the fluidity at certain regions is increased) by environmental factors (Neumann et al., 2003; Härtig et al., 2005). Since direct effect on membrane fluidity has also been observed in the case of $\mathrm{MeHg}$ (Girault et al., 1997; Schara et al., 2001), the abovementioned mechanism may apply here as well.

\section{CONCLUSIONS}

In our research a bacterial model has been used to assess toxicity of two mercury species that represent important pollutants of aquatic ecosystems at sites of industrial or mining activities.

The results showed different toxicities of $\mathrm{Hg}(\mathrm{II})$ and $\mathrm{MeHg}$ to (bacterial) cells. Meanwhile inorganic form, $\mathrm{Hg}$ (II) did not influence the growth nor induce any significant changes in fatty acid profile of $P$. putida, exposure to methylated form of mercury resulted in partial growth inhibition, which appears to be balanced by adaptive membrane changes. We showed that changes in fatty acid profile of $P$. putida resulting from $\mathrm{MeHg}$ exposure are similar to those observed as a response to organic solvents, as well as some other membrane-disrupting compounds, and are associated with (adaptive) decrease in membrane fluidity.

Despite the fact that response of $P$. putida to $\mathrm{MeHg}$ is not specific, these bacteria might possibly be used to develop a bioassay, used to indicate the potential presence of toxic bioavailable concentrations of $\mathrm{MeHg}$ in environments where mercury represents the major pollutant (i.e. Idrijca river, where $\mathrm{MeHg}$ also accumulates in freshwater fish and crabs). Neverthless, more research needs to be done to assess the influence of different physico-chemical parameters (like $\mathrm{pH}$, ionic strength etc.) as well as other potentially interfering compounds on the responsiveness of the system.

\section{REFERENCES}

Benoit G., Schwantes J.M., Jacinto G., Goudcollins M.R. 1994. Preliminary study of the redistribution and transformation of $\mathrm{HgS}$ from cinnabar mine tailings deposited in Honda Bay, Palawan, Philippines. Mar. Pollut. Bull., 28: 754-759

Bernal P., Segura A., Ramos J.L. 2007. Compensatory role of the cis-trans-isomerase and cardiolipin synthase in the membrane fluidity of Pseudomonas putida DOT-T1E. Environ. Microbiol., 9: 1658-1664

Broniatowski M., Dynarowicz-Łatka P. 2009. Search for the Molecular Mechanism of Mercury Toxicity. Study of the Mercury(II)-Surfactant Complex Formation in Langmuir Monolayers. J Phys Chem B., 113: 4275-4283

Crespo-López E.M., Lima de Sáa A., Herculanob A.M., Burbanoc R.R., Martins do Nascimento H.L. 2007. Methylmercury genotoxicity: A novel effect in human cell lines of the central nervous system. Env. Internat., 33: 141-146

Cronan J.E. 2002. Phospholipid modifications in bacteria. Curr. Opin. Microbiol., 5: 202-205

Delnomdedieu M., Boudou A., Georgescauld D., Dufourc E.J. 1992. Specific interactions of mercury chloride with membranes and other ligands as revealed by mercury-NMR. Chem. Biol. Interact., 81: 243-69

DSMZ: German collection of microorganisms and cell cultures. Braunschweig, Deutsche Sammlung von Mikroorganismen und Zellkulturen $\mathrm{GmbH}$. http://www.dsmz.de/bactnom/nam2400.htm (20. Oct. 2010)

Faganeli J., Horvat M., Covelli S., Fajon V., Logar M., Lipej L., Cermelj B. 2003. Mercury and methylmercury in the Gulf of Trieste (northern Adriatic Sea). Sci. Total Environ., 304: 315-326

Farre M., Brix R., Barcelo D. 2005. Screening water for pollutants using biological techniques under European Union Funding during the last 10 years. Trends Anal. Chem. 24: 532-545

Girault L., Boudou A., Drfourc E.J. 1997. Methyl mercury interactions with phospholipid membranes as reported by fluorescence, 31P and 199Hg NMR. Biochim Biophys Acta, 1325: 250-262

Golding G.R., Kelly C.A., Sparling R., Loewen P.C., Barkay T. 2007. Evaluation of Mercury Toxicity as a Predictor of Mercury Bioavailability. Environ. Sci. Technol., 41: 5685-5692

Han Z.X., Lv C.X., Zheng Z.R. 2008. Toxicity of mercury to Carassius auratus and the antagonistic effect of selenium. Synth. React. Inorg. Met. Org. Chem., 38: 584-590

Härtig C., Loffhagen N., Harms H. 2005. Formation of trans Fatty Acids Is Not Involved in Growth-Linked Membrane Adaptation of Pseudomonas putida. Appl. Environ. Microbiol., 71: 1915-1922

Heipieper H.J., Diefenbach R., Keweloh H. 1992. Conversion of cis unsaturated fatty acid to trans, a possible mechanism for the protection of phenol-degrading Pseudomonas putida P8 from substrate toxicity. Appl. Environ. Microbiol., 58: 1847-1852

Heipieper H.J., De Bont J.A.M. 1994. Adaptation of Pseudomonas putida S12 to ethanol and toluene at the level of fatty acid composition of membranes. Appl. Environ. Microbiol., 60: 4440-4444 
Heipieper H.J., Loffeld B., Keweloh H. 1995. The cis/trans isomerisation of unsaturated fatty acids in Pseudomonas putida S12: An indicator for environmental stress due to organic compounds. Chemosphere, 30: 1041-1051

Heipieper H.J., Maulenbeld G., Van Oirschot Q., De Bont J.A.M. 1996. Effect of environmental factors on the trans/ cis ratio of unsaturated fatty acids in Pseudomonas putida S12. Appl. Environ. Microbiol., 62: 2773-2777

Heipieper H.J., Fischer J. and Meinhardt F. 2010. Cis-Trans Isomerase of Unsaturated Fatty Acids: An Immediate Bacterial Adaptive Mechanism to Cope with Emerging Membrane Perturbation Caused by Toxic Hydrocarbons. In: Handbook of Hydrocarbon and Lipid Microbiology. Timmis K.N. (ed.). Springer Berlin Heidelberg: 1606-1602

Hines M.E., Horvat M., Faganeli J., Bonzongo J.C.J., Barkay T., Majorf E.B., Scott K., Bailey E.A., Warwick J.J., Lyons W.B. 2000. Mercury Biogeochemistry in the Idrija River, Slovenia, from above the Mine into the Gulf of Trieste. Env. Res., 83 (A): 129-139

Ivancic T., Vodovnik M., Marinsek-Logar R., Stopar D. 2009. Conditioning of the membrane fatty acid profile of Escherichia coli during periodic temperature cycling. Microbiology, 155: 3461-3463

Killian J.A., Fabrie C.H., Baart W., Morein S., de Kruijff B. 1992. Effects of temperature variation and phenethyl alcohol addition on acyl chain order and lipid organization in Escherichia coli derived membrane systems. A $2 \mathrm{H}$ - and $31 \mathrm{P}-$ NMR study. Biochim. Biophys. Acta, 1105: 253-262

Leblanc R.M., Joly L.P., Paiement J., 1984. pH-dependent interaction between methyl mercury chloride and some membrane phospholipids. Chem. Biol. Interact., 48: 237-241

Loffhagen N., Härtig C., Babel W. 2004. Pseudomonas putida NCTC 10936 balances membrane fluidity in response to physical and chemical stress by changing the saturation degree and the trans/cis ratio of fatty acids. Biosci. Biotechnol. Biochem., 68: 317-323

Mason P.R., Reinfelder J.R., Morel F.M.M. 1996. Uptake, Toxicity, and Trophic Transfer of Mercury in a Coastal Diatom. Environ. Sci. Technol., 30: 1835-1845
Mjøs S.A. 2003. Identification of fatty acids in gas chromatography by application of different temperature and pressure programs on a single capillary column. J. Chromatogr., 1015: 515-161

Marinšek Logar R., Vodovnik M. 2007. The applications of microbes in environmental monitoring. In: Communicationg Current Research and Educational Topics and Trends in Microbiology (Microbiology series, no. 1, vol. 2). MéndezVilas A. (ed.). Badajoz, Formatex: 577-585

Neumann G., Kabelitz N., Heipieper H.J. 2003. The regulation of the cis-trans isomerase of unsaturated fatty acids in Pseudomonas putida: correlation between cti activity and $\mathrm{K}+-$ uptake systems. Eur. J. Lipid Sci. Technol., 105: 585-589

Patrick L. 2002. Mercury toxicity and antioxidants: Part 1: role of glutathione and alpha-lipoic acid in the treatment of mercury toxicity. Altern, Med. Rev., 7: 456-471

Qiu G., Feng X., Wang S., Shang L. 2006. Environmental contamination of mercury from Hg-mining areas in Wuchuan, northeastern Guizhou. China. Env. poll., 142: 549-558

Schara M., Nemec M., Falnoga I., Kobal A.B., Kveder M., Svetek J. 2001. The action of mercury on cell membranes. Cell. Mol. Biol. Lett., 6: 299-304

Segall H.J., Wood J.M. 1974. Reaction of methyl mercury with plasmalogens suggests a mechanism for neurotoxicity of metal-alkyls. Nature, 248: 456-458

Sweet L.E., Zelnikoff J.T. 2001. Toxicology and immunotoxicology of mercury: a comparative review in fish and humans. J. Toxicol. Environ. Health B Crit. Rev., 4 (B): 161-205

Von Wallbrunn A., Richnow H.H., Neumann G., Meinhardt F., Heipieper H.J. 2003. Mechanism of cis-trans isomerization of unsaturated fatty acids in Pseudomonas putida. J. Bacteriol., 185: 1730-1733

Weber F.J., Isken S., De Bont A.M. 1994. Cis/trans isomerization of fatty acids as a defence mechanism of Pseudomonas putida strains to toxic concentrations of toluene. Microbiology, 140: 2013-2017 